\title{
Evaluation of Hematological Parameters in two Different Species Trout Exposed to Chlorpyrifos
}

\author{
Veysel Parlak \\ Department of Aquaculture, Faculty of Fisheries, Atatürk University. Turkey
}

*Corresponding Author: Veysel Parlak, Department of Aquaculture, Faculty of Fisheries, Atatürk University. Turkey

\begin{abstract}
Environmental pollutants are a major problem for aquaculture. The aim of this study was to evaluate the effects of chlorpyrifos, a pesticide used by agricultural producers in plant production, on some hematological parameters (hemoglobin, hematocrit, erythrocyte, leukocyte, platelet, mean corpuscular volume $(M C V)$, mean corpuscular hemoglobin $(M C H)$, and mean corpuscular hemoglobin concentration (MCHC) of rainbow trout (Oncorhynchus mykiss) and brown trout (Salmo truttafario). Fish were exposed to CPF concentrations $(1 \mu \mathrm{g} / \mathrm{L}$ and $2 \mu \mathrm{g} / \mathrm{L})$ for periods of 21 days.

In rainbow trout; dosage effects were found very significantly for leukocyte, platelet, MCV and MCHC among hematologic parameters $(P<0.01)$, whereas dosage main effects were found significantly for other parameters $(P<0.05)$. In brown trout; hemoglobin, hematocrit, erythrocytes, leukocytes, platelets, $M C H$ and MCHC were significantly affected by the treatments $(P<0.01)$. In chlorpyrifos applications, the values regarding hematologic parameters showed some differences such as increasing-decreasing and decreasing-increasing. In this study, hematological parameters will be valuable to facilitate as a potential biomarker for assessing the health status of fish.
\end{abstract}

Keywords: Rainbow trout, Hematological parameters, Brown trout, Chlorpyrifos.

\section{INTRODUCTION}

Chlorpyrifos (CPF) is intensively used pesticide based on organophosphate insecticide. CPF includes a phosphor thiol functional moiety, has been broadly used in agricultural applies to increase crop yields [1-2]. It was shown that CPF was the pollutants in surface and ground water of many countries. Furthermore, CPF has also been detected in many aquatic ecosystems, including natural and urban streams, rivers and lakes [3]. CPF is very toxic for fish even at low concentrations [4]. Therefore, fish and aquatic organisms and water ecosystems are negatively affecting the balance. There are many studies on the adverse effects of CPF toxicity in fish [5-6-7]. Fish have proved to be good models to evaluate the toxicity and effects of contaminants in previous studies. Rainbow trout and brown trout are an economically important fish species, commonly found in rivers and Dam Lake in Turkey and considered as a potential bio indicator species [8]. Exposure of fish to various chemicals can cause changes in various hematological parameters [9]. Examination of the hematological parameters of organism in studies carried out in order to determine toxic effects is important for achieving correct knowledge [8-10]. Hematology is a science that not only gives information about fish diseases but also determines the effects of nutrition and environmental factors. Fish affects all kinds of stresses, diseases, nutritional deficiencies, toxic substances, changes in water quality and other environmental factors [11]. Hematological parameters are very important diagnosis of diseases. Erythrocyte and leukocyte counts, hemoglobin, hematocrit and platelet counts can easily respond to determining stress caused by environmental pollutants. The measurement of hematological changes in the blood has an important role in predicting the toxic effects of toxic substances [12]. The study of hematology parameters in fishes has been widely used for the detection of physio pathological alterations in different conditions of stress. Consequently, in the present investigation an effort has been made to study the effect of CPF on alterations in hematological parameters of rainbow trout and brown trout to the same stressor were compared.

\section{Materials AND Methods}

\subsection{Fish Maintenance and Experimental Design}

Rainbow trout (O. mykiss) and brown trout (S. t. fario) (average weight $160 \pm 10 \mathrm{~g}$ and mean standard length of $19 \pm 2 \mathrm{~cm}$ ) were supply from Ataturk University, Faculty of Fisheries. The water was 
distributed to the 450 -literindoor fiberglasstanks $(A=15$ rainbow trout, $B=15$ rainbow trout, $C=15$ rainbow trout, $\mathrm{D}=15$ brown trout, $\mathrm{E}=15$ brown trout, $\mathrm{F}=15$ brown trout) as having a minimum of 0.5 $1 /$ min for each $\mathrm{kg}$ of fish. Water parameters has been measured during the study (water temperature 9 $\pm 1.5^{\circ} \mathrm{C}$, dissolved oxygen $9.2 \mathrm{mg} / \mathrm{l}$ and $\left.\mathrm{pH} 7.2\right) .15$ fish have been distributed per tank for a total of 6 tanks. 2 of the tanks control (one of their O. mykiss and the other S.t.fario) group and the other 4 tanks (O. mykiss and S.t.fario) have been defined as the treatment groups. As per the trial procedure for defined volume retrials, the concentrations have been reapplied every 12 hours (continuous flow system) in order the dose. We determined the constants that were lower than the negative effect level observed for the trout. Fishes were exposed to CPF concentrations of $1 \mu \mathrm{g} / \mathrm{L}$ and $2 \mu \mathrm{g} / \mathrm{L}$ for 21 days. After 21 days (chronic exposure), the five fish from each tank were randomly selected and sampled.

\subsection{Chemical}

Chlorpyrifos (480g/L chlorpyrifos, O, O-diethyl-O-(3,5,6-trichlor-2-pyridyl) phosphorothioate) was attained from a commercial manufacturer (Akdeniz Chemical Companies, Erzurum, Turkey). Chlorpyrifos were solubilized in test water. This stock was diluted in tanks to obtain experimental concentrations. The LC50 value for trout $(9 \mu \mathrm{g} / \mathrm{l})$ of chlorpyrifos was determined according to EPA [13]. For each fish species one tank was used as control (no application of pesticide), and the others were added $1 \mu \mathrm{g} / 1$ and $2 \mu \mathrm{g} /$ lchlorpyrifos, respectively. We have chosen these concentrations because it is lower than lethal concentrations for rainbow trout. Fish deaths were not observed during chemical exposure.

\subsection{Hematological Analysis}

Nearly 2 cc blood was collected from caudal vena to determine of hematological parameters. Fish from each treatment were for collection of blood by puncture of the caudal vessel using a syringe containing 10\% EDTA solution. The collected blood was separated into aliquots for different analyzes: the red blood cell (RBC), white blood cell count (WBC) and platelets (Plt) were determined according to Vanietal. [14] and Parlak[15], for analysis of hematocrit percentage (Hct), Goldenfarbet al.[16]method was used. Hemoglobin concentration $(\mathrm{Hb})$ was measured by the Collier [17] method. Hematological parameter such as the mean corpuscular volume (MCV), the mean corpuscular hemoglobin $(\mathrm{MCH})$ and the mean corpuscular hemoglobin concentration (MCHC) were calculated according to Wintrobe[18] method.

\subsection{Statistical Analyses}

The SPSS 20.0 software was used to perform all analyses and was assessed by Duncan. The data are expressed as the mean \pm SD. Significant difference was acknowledged when $\mathrm{P}<0.05$.

\section{RESUltS}

The changes in hematological parameters of the fish rainbow trout and brown trout exposed to chronic toxicity of chlorpyrifos are presented in Table 1. Chlorpyrifos exposure in rainbow trout led to a significant increased $(\mathrm{P}<0.05)$ in $\mathrm{WBC}, \mathrm{RBC}, \mathrm{Hb}, \mathrm{MCH}$ and $\mathrm{MCHC}$, but $\mathrm{MCV}$ decreased. Chlorpyrifos exposure in brown trout led to a significant increased $\mathrm{WBC}, \mathrm{RBC}, \mathrm{Hb}$, and MCHC but MCV and MCH decreased $(\mathrm{P}<0.05)$ (Table 1).

Table1. Hematological parameters of rainbow trout and brown trout.

\begin{tabular}{|c|c|c|c|c|c|c|}
\hline \multicolumn{4}{|c|}{ Rainbowtrout } & \multicolumn{3}{c|}{ Brown trout } \\
\hline Parameters & Control & $\mathbf{1} \boldsymbol{\mu g} / \mathbf{L}$ & $\mathbf{2} \boldsymbol{\mu \mathbf { g }} / \mathbf{L}$ & $\mathbf{C o n t r o l}^{\mathrm{b}}$ & $\mathbf{1} \boldsymbol{\mu g} / \mathbf{L}$ & $\mathbf{2} \boldsymbol{\mu \mathbf { g } / \mathbf { L }}$ \\
\hline WBC & $4.167^{\mathrm{a}}$ & $4.225^{\mathrm{a}}$ & $4.413^{\mathrm{b}}$ & $2.992^{\mathrm{a}}$ & $3.780^{\mathrm{b}}$ & $4.325^{\mathrm{c}}$ \\
\hline $\mathrm{RBC}$ & $2.120^{\mathrm{a}}$ & $2.468^{\mathrm{b}}$ & $2.922^{\mathrm{c}}$ & $2.006^{\mathrm{a}}$ & $2.362^{\mathrm{b}}$ & $2.780^{\mathrm{c}}$ \\
\hline $\mathrm{Hb}$ & $2.428^{\mathrm{a}}$ & $4.002^{\mathrm{b}}$ & $4.274^{\mathrm{c}}$ & $6.102^{\mathrm{a}}$ & $6.326^{\mathrm{b}}$ & $6.972^{\mathrm{c}}$ \\
\hline $\mathrm{MCV}$ & $243.396^{\mathrm{a}}$ & $221.102^{\mathrm{b}}$ & $189.226^{\mathrm{c}}$ & $284.262^{\mathrm{a}}$ & $217.929^{\mathrm{b}}$ & $187.050^{\mathrm{c}}$ \\
\hline $\mathrm{MCH}$ & $11.412^{\mathrm{a}}$ & $16.214^{\mathrm{b}}$ & $17.703^{\mathrm{b}}$ & $30.418^{\mathrm{a}}$ & $26.333^{\mathrm{b}}$ & $25.079^{\mathrm{b}}$ \\
\hline $\mathrm{MCHC}$ & $4.689^{\mathrm{a}}$ & $7.334^{\mathrm{b}}$ & $7.549^{\mathrm{b}}$ & $10.700^{\mathrm{a}}$ & $12.095^{\mathrm{b}}$ & $13.407^{\mathrm{b}}$ \\
\hline $\mathrm{Plt}$ & $9.127^{\mathrm{a}}$ & $10.123^{\mathrm{b}}$ & $10.866^{\mathrm{b}}$ & $6.994^{\mathrm{a}}$ & $7.482^{\mathrm{b}}$ & $8.954^{\mathrm{c}}$ \\
\hline
\end{tabular}

$* M C V=\left[P C V(\%) / R B C\left(10^{6}\right)\right] \times 10 \mu m^{3} ; M C H=\left[H b(g) / R B C\left(10^{6}\right)\right] \times 10 \mathrm{pg} ; M C H C=[H b(g) / P C V(\%)] x$ 100 g per 100 ml, RBC: Red blood corpuscle count; Hb: Hemoglobin; PCV: Packed cell volume; MCV: Mean corpuscular volume; MCHC: Mean corpuscular hemoglobin; WBC: White blood cell count. Means sharing the same letter in the same row are not significantly different $(p>0.05)$ 
Table 1 shows blood parameters changes such as erythrocyte count, leukocyte count, platelet count, hemoglobin, hematocrit, MCV, MCH and $\mathrm{MCHC}$ in rainbow and brown trout. The data revealed decreasing or increasing differences in all hematological parameters, only the differences in $\mathrm{RBC}, \mathrm{Hb}$ and MCV were statistically significant $(\mathrm{P}<0.05)$ in rainbow and brown trout. After the exposure period, compared with those obtained in the control samples, the MCV in rainbow trout samples were relatively decreased, while other parameters were relatively increased. After the exposure period, compared with those obtained in the control samples, the MCV and $\mathrm{MCH}$ in brown trout samples were relatively decreased, while other parameters were relatively increased.

\section{DISCUSSION}

Hematology is the science that investigate the organs that make up blood cells and blood cells. Hematological analysis is very important for the diagnosis of fish diseases. Factors such as hemoglobin break down, decrease in erythrocytes and amount of hematocrit can be an indicator of anemia [19]. Hematologic parameters are indicators used to identify physiological and biochemical changes caused by stress factors in fish [8-20].

Reductions in hemoglobin value are related to the destruction of cells due to the harmful effect of pesticide. The decrease in hemoglobin value of fish exposed to xenobiotics is thought to be due to the deterioration of iron synthesis mechanism due to the inhibition of aerobic glycolysis [21]. The increase in hemoglobin level is considered as a kind of adaptation. Disruption of the Osmoregulation balance, hypoxia and decreased blood fluidity cause an increase in hemoglobin level [22]. Since hematocrit level is proportional to the number of erythrorhitoids, blood is an important parameter that informs the oxygen transport capacity and the functions of erythropoietic tissues [23]. Hematocrit is generally reduced as blood fluid increases in the anemia. In fish studies, it was determined that the number of erythrocytes and hematocrit changes depending on species, medium concentration and duration of exposure [24].

As a consequence of chronic administration, it is considered that the hematocrit level is decreased by decreasing the number of red blood cells or by hemodilution. Xenobiotics cause changes in the nucleus and cell structure by changing the membrane properties of erythrocytes [25-26]. The increase in the number of $\mathrm{RBCs}$ in fish treated with chlorpyrifos after chronic treatment showed that osmoregulation and gill tissue were not affected by pesticide. In the study, the results obtained for RBC are similar to those obtained in other studies [27-28-29]. The increase in the number of WBCs can result from protective response against immune response and pesticide stress. Leukocytes are the most important cells of the immune system because of their defense system function. Pesticide exposure increases lymphocyte release from related tissues under toxic stress, which can lead to an increase in WBC count [30]. The increase in leukocyte count can be explained by the toxic damage caused by the defense system response to the fish or by stressed fish trying to establish homoeostasis balance [31]. The increase in platelet count can be demonstrated by the amount of xenobiotic substance in the body, the adverse effects on the blood-dependent immune system, the decrease in the amount of oxygen in the blood cells, and the response to the spleen [32]. In the case of hypoxia, fishes increase the amount of MCV and MCH of erythrocytes to get through this condition. The increase in these values is due to the destruction or non-production of erythrocytes. They reported that the stress factor caused an increase in MCV and a decrease in MCHC [33]. The increase in MCV was defined as endosmosis, and hemodilution would occur if this value increased more. The fish respond by increasing the MCV and MCH of erythrocytes to combat the hypoxia that the stress factor produces. In addition, toxic stress can lead to a decrease in $\mathrm{Hg}$ values at the same time as the breakdown of Erythrocytes [34]. The decrease in Hg content may be due to the hemoglobinization or shrinkage of erythrocytes due to the toxic effect of chlorpyrifos in the erythropoietic tissue [35-36]. Consequently, the resulting data indicate that chlorpyrifos exposure caused hematological changes in both fish species. Hematological parameters give information about the physiological status of the fish. Determining the level of pollution in the aquatic environment will be a step in the prevention of fish diseases and deaths. The data we obtained in our study indicate that hematology parameters are effective in determining pesticide toxicity. These data will contribute to toxicology studies and can be used in pollution monitoring programs and ecotoxicological risk assessment studies. 


\section{REFERENCES}

[1] Xing, H., Zhang, Z., Yao, H., Liu, T., Wang, L., Xu, S., Li, S. Effects of atrazine and chlorpyrifos on cytochrome P450 in common carp liver. Chemosphere. 104:244-250. DOI: 10.1016/j.chemosphere. 2014.01.002. (2014).

[2] Jeon, H.J., Lee, Y.H., Kim, M.O.J., Choi, S.D., Park, B.J., Lee, S.E. Integrated biomarkers induced by chlorpyrifos in two different life stages of zebrafish (Danio rerio) for environmental risk assessment. Environmental Toxicology Pharmacology. 43:166-74. DOI: 10.1016/j.etap.2016.03.010. (2016).

[3] Yuan, Y., Chen, C., Zheng, C., Wang, X., Yang, G. Residue of chlorpyrifos and cypermethrin in vegetables and probabilistic exposure assessment for consumers in Zhejiang Province, China. Food Control. 36: 63-68. (2014).

[4] Barron, M., Woodburn, B. Ecotoxicology of chlorpyrifos. Environmental Contamination Toxicology. 144:1-93. (1995).

[5] Sandahl, J.F., Baldwin, D.H., Jenkins, J.J., Scholz, N.L. Comparative thresholds for acetylcholinesterase inhibition and behavioral impairment in coho salmon exposed to chlorpyrifos. Environmental Toxicology and Chemistry. 24 (1) (2005), pp. 136-145. (2005).

[6] Kavitha, P., Rao, J.V. Toxic effects of chlorpyrifos on antioxidant enzymes and target enzyme acetylcholinesterase interaction in mosquito fish, Gambusiaaffinis. Environmental Toxicology Pharmacology. 26(2):192-8. DOI: 10.1016/j.etap.2008.03.010. (2008).

[7] Halappa, R., David, M. Behavioural Responses of the Freshwater Fish, Cyprinuscarpio (Linnaeus) Following Sublethal Exposure to Chlorpyrifos. Turkish Journal of Fisheries and Aquatic Sciences. 9: 233238.DOI:10.4194/trjfas.2009.0218. (2009).

[8] Parlak, V., Atamanalp, M. Investigation of Chronic Effects of Alfa-Cypermethrın on Haemototoxıc Parameters in The Rainbow Trout (Oncorhynchus mykiss). Aquaculture Studies. Vol 17, Num, 3 (Pages: 259-272). DOI:10.17693/yunusae.vi.304127. (2017).

[9] Heath, A.G. Water Pollution and Fish Physiology. (second ed.), Lewis Publishers, Boca Raton. (1995).

[10] Lenhardt,M. 1992. Seasonal changes in some blood chemistry parameters and in relative liver and gonad weights of pike (Esoxlucius L.) from the River Danube.journal of fish biology. 40-5. Pp. 709-718.

[11] Martinez, C.B.R., Souza, M.M.Acute effects of nitrite on ion regulation in two neotropical fish species. Comparative and Biochemistry Physiology. pp. 151-160. (2002).

[12] Kulkarni, R., Barad, V. Haematological and Blood Biochemical Changes in the Fresh Water Fish, Notopterusnotopterus (Pallas) Exposed to Acidic Medium. International Letters of Natural Sciences. 23009675, Vol. 45, pp 27-33.DOI: 10.18052/www.scipress.com/ILNS.45.27. (2015).

[13] EPA.Chlorpyrifos. Alıntılanmaadresi: https://www.epa.gov/ingredients-used-pesticide-products/chlorpyr ifos. (29.10.2018). (2018).

[14] Vani, T., Saharan, M., Mukherjee, S.C., Ranjan, R., Kumar, R., Brahmachari, R.K.Deltamethrin induced alterations of hematological and biochemical parameters in fingerlings of Catlacatla (Ham) and their amelioration by dietary supplement of vitamin C. Pesticide Biochemistry Physiology. 101:16-20. DOI: 10.1016/j.pestbp.2011.05.007. (2011).

[15] Parlak, V. Gökkuşağı Alabalıklarında (OncorhynchusMykiss) Akut ve Kronik Alfa Sipermetrin Uygulamalarının Hematotoksik, Hepatotoksik Ve Nefrotoksik Etkilerinin Araştırılması.[DoktoraTezi]. Atatürk Üniversitesi. (2016).

[16] Goldenfarb, P.B., Bowyer, F.P., Hall, E., Brosious, E. Reproducibility in the hematology laboratory: the microhematocrit determination. American Journal of Clinical Pathology. vol. 56, no. 1, p. 35-39. (1971).

[17] Collier, H.B.Standardizations of blood haemoglobin determinations. Canadian Medical Association Journal, vol. 50, no. 6, +p. 550-552. (1944).

[18] Wintrobe, M.M. Variations in the size and hemoglobin content of erythrocytes in the blood of various vertebrates. Folia Hematological. vol. 51, no. 32, p. 32-49. (1934).

[19] Wimbley, T.D.J.,Graham, D.Y. Diagnosis and management of iron deficiency anemia in the 21 st century. Therapeutic Advances in Gastroenterology.4(3)- 177184.DOI:10.1177/ 1756283X11398736. (2011).

[20] Atamanalp, M. Farklıyetiştirmesistemlerinin (havuzvekafes) gökkuşağıalabalığı (O. mykissWalbaum, 1792) hemoglobin, hematokritve sediment seviyeleriüzerineetkileri. EgeÜniversitesiSuÜrünleriDergisi, 20 (1-2), 81-86. (2003).

[21] Banaee, M., Mirvagefei, G.R., Rafei, B., Amiri, M. Effect of sub-lethal diazinon concentrations on blood plasma biochemistry. International Journal of Environmental Research.2: 189-198.DOI:10.22 059/IJER. 2010.193. (2008).

[22] Windsor, J.S., Rodway, G.W. Heights and hematology: the story of hemoglobin at altitude. Postgrad Medicine of Journal. 83(977): 148-151.DOI:10.1136/pgmj.2006.049734. (2007). 
[23] Witeska, M. Stress in Fish Hematological and Immunological Effects of Heavy Metals. Electronic Journal of Ichthyology. 1, 35-41. (2005).

[24] Arslan, M., Karaytuğ, S.,Cicik, B.BakırınClariaslazera (Valenciennes, 1840)'da dokuglikoj enveserum glukozdüzeyiüzerineetkileri.EgeÜniversitesiSuÜrünleriDergisi, 23(1/1): 23-27.(2006).

[25] Grathwohl, K.W., Bruns, B.J., LeBrun, C.J., Ohno, A.K., Dillard, T.A., Cushner, H.M. Does hemodilution exist? Effects of saline infusion on hematologic parameters in euvolemic subjects. South Medicine Journal. 89(1):51-5. (1996).

[26] Parlak, V. Evaluation of apoptosis, oxidative stress responses, AChE activity and body malformations in zebrafish (Danio rerio) embryos exposed to deltamethrin. Chemosphere. Volume 207, Pages 397-403. DOI: 10.1016/j.chemosphere.2018.05.112. (2018).

[27] Mazon, A.F., Monteiro, E.A.S., Pinheiro, G.H.D., Fernadez, M.N.Hematological and Physiological changes induced by short-term exposure to copper in the freshwater fish, Prochilodusscrofa. Brazil Journal of Biology. vol.62 no.4a. (2002).

[28] Martins, M.L., Mouriño, J.L.P., Amaral, G.V., Vieira, F.N., Dotta, G., Jatobá, A.M.B., Pedrotti, F.S., Jerônimo, G.T., Buglione-Neto, C.C., Pereira-Jr, G. Haematological changes in Nile tilapia experimentally infected with Enterococcus sp. Brazil Journal of Biolody. 68(3): 657-661. (2008).

[29] Witeska, M.Erythrocytes in teleost fishes: a review. Journal Zoology and Ecology Volume 23- Issue 4. DOI: 10.1080/21658005.2013.846963. (2013).

[30] Hundekari, I.A., Suryakar, A.N.,Rathi, D.B. Acute organo-phosphorus pesticide poisoning in North Karnataka, India: oxidative damage, haemoglobin level and total leukocyte. Africa Health Science. 13(1): 129-136.DOI: 10.4314/ahs.v13i1.18.(2013).

[31] Alwan, S.F., Hadi, A.A., Shokr, A.E. Alterations in hematological parameters of fresh water fish, Tilapia zillii, exposed to aluminum. Garyounis University Press Journal of Science and Its Applications. Vol. 3, No. 1, pp 12-19. (2009).

[32] Mbarki, S., Dhibi, S., Bouzenna, H., Elfeki, A., Hfaiedh, N. Effects of $\mathrm{MgCl}_{2}$ supplementation on blood parameters and kidney injury of rats exposed to $\mathrm{CCl}_{4}$. Open Life Science. 11: 250-258.DOI: https://doi. org/10.1515/biol-2016-0035. (2016).

[33] Ahmadifar, E., Falahatkar, B., Akrami, R. Effects of dietary thymol-carvacrol on growth performance, hematological parameters and tissue composition of juvenile rainbow trout, Oncorhynchus mykiss. Journal of applied ichthyology. 27, 1057-1060.10.1111/j.1439- 0426.2011.01763.DOI:10.1111/j.1439-0426.2011. 01763.x. (2011).

[34] Hedayati, A., Hassan, E., Niazie, N. Hematological changes of silver carp (hypophthalmichthys molitrix) in response to Diazinon pesticide. Journal of Environmental Health Science Engineer. 2015; 13: 52.DOI:10.1186/s40201-015-0208-9. (2015).

[35] Reitzenstein, J.E., Yamamoto, L.G.,Mavoori, H. Similar erythrocyte sedimentation rate and C-reactive protein sensitivities at the onset of septic arthritis, osteomyelitis, acute rheumatic fever. Pediatric Report.2(1)-18. DOI:10.4081/pr.2010.e10.(2010).

[36] Hashemi, R., Majidi, A., Motamed, H., Amini, A., Najari, F., Tabatabaey, A. Erythrocyte sedimentation rate measurement using as a rapid alternative to the westergren method. Emergency (Tehran). 3(2): 50-53. (2015).

Citation: Veysel Parlak "Evaluation of Hematological Parameters in two Different Species Trout Exposed to Chlorpyrifos”. International Journal of Innovative Studies in Aquatic Biology and Fisheries, 5(1), pp.12-16. http://dx.doi.org/10.20431/2454-7670.0501003

Copyright: (C) 2019 Authors. This is an open-access article distributed under the terms of the Creative Commons Attribution License, which permits unrestricted use, distribution, and reproduction in any medium, provided the original author and source are credited. 